\title{
Redefining disability: a rejoinder to a critique
}

\section{Solveig Magnus Reindal}

Recently, scholars have argued that disability activists' redefinition of 'disability' as a social problem, rather than a medical problem, is maleficent, unjust, and inconsistent. It seems that the discussion on whether disability is a medical or a social category is not settled and that disability is an essentially contested concept. However, the question is: What is the social aspect in disability? It appears that there is some confusion as to what the social is in a social definition of disability. The article pursues possible reasons for this confusion by investigating the critique of the social model. This is followed by a discussion on what a possible space for the social might be in a social definition of disability. Such a space is illuminated by using the framework of the World Health Organization's International Classification of Functioning Disability and Health (ICF). The article suggests that disability as a social category is not inconsistent if reframed within a social relational model of disability.

Keywords: disability theory, ICF, philosophy

\section{Disability: examining the critique of the social model}

The issue of whether disability is a medical or a social category is important for a host of reasons. How disability is understood is relevant in relation to ethical discussions within bioethics as pre-implantation genetic diagnosis (PDG) in relation to IVF (Cox-White \& Boxall 2009; Harris 2000, Reindal 2000). Within the field of special educational needs, the understanding of disability influences discussions within the field of inclusive education (Reindal 2008). However, it is problematical that one sector of society, e.g. medical and health services, should adhere to one understanding of disability, while another sector, e.g. education, should adhere to another under- 
standing. Often people with impairments participate in different arenas in society and it is difficult to build systems and practices that are coherent if the perception of disability is not common across all sectors within society. For example, in order to adapt the educational situation to accommodate some pupils with impairments, special education and related services within rehabilitation need to cooperate.

However, within bioethical discussions holding onto a medical model of disability, there seems to be a confusion regarding what the 'social' part is in a social definition of disability. Some of this misunderstanding is derived from disability studies' unclear elaborations of their understanding of disability. Other misunderstandings arise due to bad reading and willingness to choose the most plausible interpretation of a statement (suspicious hermeneutics).

Critiques of social models can be divided into at least three types: 1) internal critiques, 2) critiques from related research fields, and 3) philosophical critiques (Reindal 2008: 141). The internal critique of the social model is partly initiated by self-critique in order for architects of models to be able to improve their models. The social model developed from the milieu around the Union of the Physically Impaired Against Segregation (UPIAS) in England, with contributions from Paul Abberley, Len Barton, Vic Finkelstein, Paul Hunt, and Mike Oliver, just to mention some of the contributors. The main target of the social model was to break the linear causal link between impairment and the state of being disabled, which in their view was prominent in individual models and especially in the medical model. Breaking this causal link on a theoretical level, the social model faced the problem of how to 'fit' with the personal experience of impairments, as the social model was not designed to deal with the personal restrictions of impairment, but rather the social barriers of disabilities (Oliver 1996: 38). Utterances like these were met by critique from other advocates of the social model, who emphasised the importance of personal experiences of impairment (Crow 1996: 60) The proponents of the social model started to highlight contingency, and engaged in sociological and philosophical investigations in an attempt to deconstruct the phenomenon of disability in order to show that the phenomenon is not static, a-historical, or universal (Corker \& Shakespeare 2002; Danforth \& Rhodes 1997). The challenge was then to understand the interplay between impairment and the phenomenon of disability: How contingent was this relationship? In addition, if there was not necessarily a cause and effect relationship between impairment and disability, how was one to understand the fact that often people with impairments experience oppression and discrimination as a group? The medical sociologist Mike Bury argues that if there are no underpinning individual problems initially, then social reactions in the form of oppression, exclusion, discrimination, and so forth have nothing to respond to 
(Bury 1996: 30). In the aftermath, much of the grounds for confusion and disagreement in debates have been related to the issue of how to explain this interplay within the various positions of the social model as either materialist or idealist in its underpinnings. This confusion is also prevalent in other fields where impairment and disability is an issue, such as within debates concerning special educational needs and promoting the social model:

Special needs are not needs that arise in a child with disabilities with regard to a system that is fixed. Rather they are needs that arise between the child and the educational system as a whole when the system fails to adopt itself to the characteristics of the child (Dyson, cited in Norwich, 1993, p. 50). (Terzi 2005: 448)

Interpretations such as those referred to above show the imprecise understanding of what the social aspects of disability are, when scholars endorse an understanding of disability emphasising social barriers. In addition, comments such as the one cited in Terzi (2005) have often given rise to a second critique, whereby related research fields criticise the social model for over-socialising the phenomenon of disability. This type of critique is prominent within the sociology of medicine and bioethics (Cox-White 2009; Bury 1996; Harris 2000; Richards 2002). However, the issue of oversocialising the phenomenon of disability attacks more idealistic underpinnings of the social model, drawing on social constructivism. The constructivist understanding of the social model, also often labelled the postmodern position (Thomas 2004), relativises the phenomenon of disability more radically. An example can be found in the writings of Claire Tregaskis, where she argues that disability could be eradicated if society was organised in ways that took the needs of all its citizens into account (Tregaskis 2004a; 2004b: 604). Such a broad constructivist position (Collin 1997) as Tregaskis argues for, is by some bioethicists drawn into the absurd, as exemplified by thought experiments:

\footnotetext{
No matter how conveniently a paraplegic might move around in a town there would be problems about trying to keep with a party climbing in the Himalayas - and it would be difficult to attribute this to any kind of social construction. And if such problems appear in thought experiments about one particular disability, they appear far more when you consider the endless types and degrees of disability that exists, and imagine trying to construct environments that could cope with them all. (Richards 2002: 710)
}

The point Richards touches upon here is a general problem within the social model drawing on social constructivism, namely the interpretation of restriction to activity (i.e. disability) as caused by social barriers only, and that impairment per se is not relevant to the experience of restriction of activity (Reindal 2008: 142). This, of course, is absurd, as J.R. Richards appropriately points out. According to Carol Thomas, the basis for this, is the blunt 
social modellist assertions to the position that 'all restriction of activity are caused by social barriers'. It is then easy to slide into making logical counter assertions such as this: impairment does not cause restrictions of activity because the social models tell us that ALL restrictions of activity are caused by social barriers. (Thomas 2004: 579, emphasis in original)

However, the proponents of the social model, adhering to a more materialist position, have not denied the issue of impairment, nor do they deny an underlying reality or experience that differentiates between disabled and non-disabled people, and that causes restrictions (Barnes \& Mercer 2003: 78-79). They clearly hold that a 'disabled body and identity do have a 'material reality' (Barnes, Mercer \& Shakespeare 1999: 94). However, according to disability activists, the problem with living with impairments does not lie in having an impaired body but instead lies in social barriers. On the other hand, the shift in focus away from the body and towards social barriers has often resulted in the counter-assertions pointed out by Thomas above.

The quote from Richards (2002) reveals the understanding of the social model according to scholars within bioethics: namely, that the social model is denying the issue of impairments per se and its restrictiveness. A recent example of this perception of the social model by bioethics is demonstrated in the writings of Becky Cox-White and Susanna Flavia Boxall: 'Alternatively, disability activists argue that social beliefs, attitudes, policies and practices - not impairment per se - limit opportunity' (Cox-White \& Boxall 2009: 558). In contrast, according to Cox-White and Boxall, the medical definition of which impairments are inherently disabling, and intrinsically limit the opportunities of persons who possess them, albeit to varying degrees, range from minimal to devastating. Thus, proponents of a medical definition deny even the 'possibility that impairments are disabling in only some contexts' (Cox-White \& Boxall 2009: 558). However, I am reluctant to believe that scholars holding onto the medical view would not agree that impairments are disabling in only certain contexts.

If one considers, for example, the issue of school attendance and severely reduced eyesight, in Northern countries, this is not a problem as glasses are commonly available and it is easy to find an optician. However, within countries of the South, such as in rural areas in Africa, children with reduced sight do not have the same possibilities to obtain glasses, for at least two reasons: lack of money and lack of access to opticians. Consequently, school attendance is difficult with reduced eyesight. However, if such children moved to central parts of the country and are adopted by wealthier families, their reduced function would not be a hindrance to school attendance. This raises the question of whether the hindrance to school attendance for children with impaired vision is the impairment per se or contextual factors.

The main idea behind the social model has been to illustrate and identify this relational specificity of reduced function and point to the social 
aspects which contribute to a developing state of disability. Hence, the proponents of the social model stress the importance of identifying and criticising the understanding and the policy-making in societies constructed on biological differences between the disabled and non-disabled.

The third critique of the social models comes from the philosophy of science, where the social model is affected by the same general critiques as other social constructionist positions and relativist variants of sociology, because the distinction between ontology and epistemology is dissolved (Reindal 2008: 142). Because of this unclear border between categories, these positions have difficulty in producing social facts due to lack of construct validity (Collin 1997: 74). This is, for example, prevalent within Marxist analyses of the social model which argue that the ideology of normality originated with the rise of capitalism, with the accompanied need for workforces defined by people's capacity to be useful and productive (Oliver 1990). Such elaborations and constructions of social facts face the general critique raised against Marxist analyses, the difficulty of indicating which historical and economic context the phenomenon of disability was generated within, as the phenomenon of disability also existed before the rise of capitalism in Western culture (Thomas 2004: 572).

\section{Disability: what is social in disability?}

Does this critique jeopardise the whole idea of disability being a relational specificity that emerges within social contexts, and not just a straightforward consequence of a reduced function? I have argued elsewhere (Reindal 1998 ; 2008; 2009) that the logical distinction between necessary and sufficient reasons might illuminate the interplay between impairment, its effects, and disability, and have pointed to the possible space of 'the social' within a social definition of disability.

A necessary condition is one which is a prerequisite: for example, being able to read is a necessary condition for making sense of a text. However, reading is not a sufficient condition, because one might be able to read, yet still find a text too abstract or difficult to understand. Being able to read does not guarantee that one will be able to make sense of a text. However, if one cannot read, for example, English, one certainly will not make any sense of, for instance, the present article (Reindal 2008: 143). A sufficient condition is one which, if met, will guarantee that whatever is in question will be satisfied. Having a particular impairment implies what Carol Thomas calls impairment effect (Thomas 2004; 2007). Experiences of impairment effects are necessary for understanding disablement in certain circumstances. However, this alone is not a sufficient condition, since whether an impairment results in disablement will differ according to time, changing cir- 
cumstances, and various contextual conditions (Reindal 2008: 144). Further, one cannot be a disabled person without being impaired in some sense in the first place. An effect of a severe reduction in sight would mean, for example, not being able to visit a bookshop and read books printed in black writing. However, if texts were made available in Braille format or scanned, the effects of the impairment would be reduced, and the texts could be read. Yet, for those living in environments without technical aids and equipment or who are not trained in Braille, their impairment would not be facilitated and effectively they would become more disabled.

According to Carol Thomas, what has been lost in the social model is the relational aspect (Thomas 2004: 579), which I hold is possible to illuminate with reference to necessary and sufficient reasons. Furthermore, this distinction makes clear that a social definition of disability is not in every respect inconsistent, as some claim (Cox-White \& Boxall 2009; Harris 2000). Recently, Vehmas and Mäkelä (2009) have demonstrated this relational specificity between impairment and disability by using Searle's distinction between brute and institutional facts, which states the same point acknowledging some initial objective reality. Building on this distinction, disability is understood as a relational phenomenon that consists of the relation between natural properties or features (impairments) on the one hand, and the surrounding social and physical world on the other (Vehmas \& Mäkelä 2009: 44).

An impairment effect is a necessary consequence of an impairment and this effect has both social and personal implications for an individual. However, within a social relational view on disability, the impairment effect is not equivalent to the state of being disabled. Disability is something imposed on top of the impairment effect, due to ideological, social and environmental circumstances. For a more thorough elaboration of the argument for a social relational model see Reindal (2008; 2009). In the following, I will clarify the importance of distinguishing between impairment, impairment effects, and disability by using the framework of the World Health Organization's International Classification of Functioning Disability and Health (ICF).

\section{The ICF framework and social aspects of a definition of disability}

In its present form, the ICF is the result of many revisions, with the latest version published in 2007, the ICF for children and youths (ICF-CY). Although the ICF-CY has incorporated aspects concerning children and youths, the understanding of impairment and disability in its framework is the same as that endorsed by the ICF in 2001 (Reindal 2009). The ICF is a 'bio-psychological' model which attempts to make a synthesis of individual 
and social models. Its conceptual framework consists of two parts: 1) functioning and disability and 2) contextual factors. In this framework, functioning is an umbrella term encompassing all body functionings, activities, and participation; similarly, disability covers impairments, activity limitations, and participation restrictions (WHO 2001: 3). The term 'Activity limitation' has replaced the term 'disability', which was used in the 1980 version of the ICIDH (International classification of illness disability and health). In addition, the term 'Participation restriction' has replaced the term 'handicap', used in 1980 version of the ICIDH (WHO 2001: n17 n18). In 1980, the revision process of the WHO abandoned the term 'handicap' and used 'disability' to cover all three perspectives: bodily, individualist, and social. Disability is thus conceived as the interaction of health characteristics and contextual factors (WHO 2007: 255).

ICF can assist in identifying where the principal 'problem' of disability lies, whether it is in the environment by way of a barrier or the absence of a facilitator, the limited capacity of the individual himself or herself, or some combination of factors. (WHO 2007: 256)

Table I An averview of the ICF (WHO 2001: 14)

\begin{tabular}{|c|c|c|c|c|}
\hline \multirow[b]{2}{*}{ Components } & \multicolumn{2}{|c|}{$\begin{array}{l}\text { Part I: Functioning and } \\
\text { Disability }\end{array}$} & \multicolumn{2}{|c|}{ Part 2: Contextual Factors } \\
\hline & $\begin{array}{l}\text { Body Functions } \\
\text { and } \\
\text { Sinucture }\end{array}$ & $\begin{array}{l}\text { Activities and } \\
\text { Participation }\end{array}$ & $\begin{array}{l}\text { Environmental } \\
\text { Factors }\end{array}$ & Personal Factors \\
\hline Domains & $\begin{array}{l}\text { Body functions } \\
\text { Body structures }\end{array}$ & $\begin{array}{l}\text { Life areas (tasks, } \\
\text { actions) }\end{array}$ & $\begin{array}{l}\text { External } \\
\text { influences on } \\
\text { functioning and } \\
\text { disability }\end{array}$ & $\begin{array}{l}\text { Internal } \\
\text { influences on } \\
\text { functioning and } \\
\text { fisability }\end{array}$ \\
\hline Constructs & $\begin{array}{l}\text { Change in body } \\
\text { functions } \\
\text { (psychological) } \\
\text { Change in body } \\
\text { structures } \\
\text { (anatomical) }\end{array}$ & $\begin{array}{l}\text { Capacity } \\
\text { Executing tasks } \\
\text { in a standard } \\
\text { environment } \\
\text { Performance } \\
\text { Executing tasks } \\
\text { in the current } \\
\text { environment }\end{array}$ & $\begin{array}{l}\text { Facilitating or } \\
\text { hindering } \\
\text { impact of } \\
\text { features of the } \\
\text { physical, social, } \\
\text { and attitudinal } \\
\text { world }\end{array}$ & $\begin{array}{l}\text { Impact of } \\
\text { attributes of the } \\
\text { person }\end{array}$ \\
\hline \multirow[t]{2}{*}{ Positive aspects } & $\begin{array}{l}\text { Functional } \\
\text { and structural } \\
\text { integrity }\end{array}$ & $\begin{array}{l}\text { Activitics } \\
\text { Participation }\end{array}$ & Facilitators & Not applicable \\
\hline & \multicolumn{2}{|c|}{ Functioning } & & \\
\hline \multirow[t]{2}{*}{$\begin{array}{l}\text { Negative } \\
\text { aspects }\end{array}$} & Impairment & $\begin{array}{l}\text { Activify } \\
\text { Limitation } \\
\text { Participation } \\
\text { Restriction }\end{array}$ & \multirow[t]{2}{*}{$\begin{array}{l}\text { Barricrs } \\
\text { Hindrances }\end{array}$} & \multirow[t]{2}{*}{ Not applicable } \\
\hline & \multicolumn{2}{|c|}{ Disability } & & \\
\hline
\end{tabular}


In the ICF there is an interaction between individual and social elements. The 'problem' of disability can be both individual and social. In other words, the phenomenon of disability as perceived in the ICF can be a result not only of barriers but also of individual restrictions (Reindal 2009). However, this elaboration of where the problem lies confirms Carol Thomas' (2004) critique that even though disability is viewed in relation to social barriers, the interplay between impairment and disability is restrictive in the ICF model. The perception of this interplay as restrictive implies an understanding of disability as a disadvantage, a deviation from normal standard, compared to unjust structures as a view of oppression would emphasise. This is the main difference between the approaches within the sociology of medicine and disability studies (Thomas 2007: 15).

The ICF table (Table 1) indicates that although the interplay between impairment and disability is interactive it is clear that the perception of disability is not something that is imposed upon the individual but rather is a result of restriction, as the phenomenon of disability is placed within Part 1 (Reindal 2009). The contextual factors (Part 2) can thus either facilitate or hinder individual disability. The issue of disability is not contingent upon contextual factors but is a result of restriction, as the linear understanding of the relationship between impairment and disability is kept in the ICF framework. In this sense, disability as a state is a consequence of individual impairment, although this is more or less prevalent relative to contextual factors.

The ICF framework links disability and restrictions to activity to general norms. Activities and roles that are statistically normal or considered positively desirable in the relevant cultural context constitute the norm (Reindal 2009). This renders the ICF within an overarching social deviance approach to the phenomenon of disability. However, if we now conceptualise the social relational model within the same framework, disability is something that emerges on top of impairment effects, dependent of contextual barriers.

In Table 2 the interplay between impairment and disability is also illustrated in two parts: Part 1 consists of Functioning and impairments effects, while Part 2 consists of Contextual factors and disability. Impairment effects are the negative aspects of impairment, which result in activity limitation and participation restrictions. Within contextual factors, there are both external and internal influences on functioning and the impairments effects. This is the social space where the effects of impairment are experienced. However, the state of being disabled is something that emerges as a negative aspect due to the experiences which social space barriers and hindrances bring about. The social relational model of disability makes it possible to engage in discussions within bioethics concerning aspects of the 
common good without reference to statistical normality but in relation to theories of human flourishing, as for example in the capability approach (Reindal 2009).

Table 2 The social-relation model illuminated within the framenork of the ICF (Reindal 2009: 166)

\begin{tabular}{|c|c|c|c|c|}
\hline \multirow[b]{2}{*}{ Components } & \multicolumn{2}{|c|}{$\begin{array}{l}\text { Part 1: Functioning and } \\
\text { impairment effects }\end{array}$} & \multicolumn{2}{|c|}{$\begin{array}{l}\text { Part 2: Contextual Factors } \\
\text { Disability }\end{array}$} \\
\hline & $\begin{array}{l}\text { Body Functions } \\
\text { and } \\
\text { Structure }\end{array}$ & $\begin{array}{l}\text { Activities and } \\
\text { Participation }\end{array}$ & $\begin{array}{l}\text { Environmental } \\
\text { Factors }\end{array}$ & Personal Factors \\
\hline Domains & $\begin{array}{l}\text { Body functions } \\
\text { Body structures }\end{array}$ & $\begin{array}{l}\text { Life areas (tasks, } \\
\text { actions) }\end{array}$ & $\begin{array}{l}\text { External } \\
\text { influences on } \\
\text { functioning and } \\
\text { impairment } \\
\text { effocts }\end{array}$ & $\begin{array}{l}\text { Internal } \\
\text { influences on } \\
\text { functioning and } \\
\text { impairment } \\
\text { effects }\end{array}$ \\
\hline Constructs & $\begin{array}{l}\text { Change in body } \\
\text { functions } \\
\text { (psychological) } \\
\text { Change in body } \\
\text { structures } \\
\text { (anatomical) }\end{array}$ & $\begin{array}{l}\text { Capacity } \\
\text { Executing tasks } \\
\text { in a standard } \\
\text { environment } \\
\text { Performance } \\
\text { Exccuting tasks } \\
\text { in the current } \\
\text { environment }\end{array}$ & $\begin{array}{l}\text { Facilitating or } \\
\text { hindering } \\
\text { impact of } \\
\text { features of the } \\
\text { physical, social, } \\
\text { and attitudinal } \\
\text { world }\end{array}$ & $\begin{array}{l}\text { Impact of } \\
\text { attributes of the } \\
\text { person }\end{array}$ \\
\hline Positive aspects & $\begin{array}{l}\text { Functional } \\
\text { and structural } \\
\text { integrity }\end{array}$ & $\begin{array}{l}\text { Activities } \\
\text { Participation }\end{array}$ & Facilitators & Not applicable \\
\hline & \multicolumn{2}{|c|}{ Functioning } & & \\
\hline \multirow[t]{2}{*}{$\begin{array}{l}\text { Negative } \\
\text { aspects }\end{array}$} & Impaiment & $\begin{array}{l}\text { Activity } \\
\text { Limitation } \\
\text { Participation } \\
\text { Restriction }\end{array}$ & $\begin{array}{l}\text { Barriers/ } \\
\text { Hindrances }\end{array}$ & \multirow[t]{2}{*}{ Not applicable } \\
\hline & \multicolumn{2}{|c|}{ Impairment effecs } & Disability & \\
\hline
\end{tabular}

\section{Concluding remarks}

This way of conceptualising disability within the context of a social-relational model opens up for ethical consideration and the possibility of revealing unjust ideologies, practices and structures. The elaboration of the interplay between impairment, impairment effects and disability in Table 2 enables a social approach, stressing ethical aspects in comparison to Table 1 which resembles a deviance approach, emphasising restrictions relative to a statistical norm. 


\section{Literature}

Barnes, C. \& Mercer, G. (2003) Disability Key Concepts. Cambridge: Cambridge Polity Press.

Barnes, C., Mercer, G. \& Shakespeare, T. (1999) Exploring Disability: A Sociological Introduction. Cambridge, MA: Polity Press.

Bury, M. (1996) Defining Impairment and Disability: Challenges and Responses. In Exploring the Divide: Illness and Disability, eds. C. Barnes \& G. Mercer, pp. 1739. Leeds: Disability Press.

Collin, F. (1997) Social Reality. The Problems of Philosophy. London: Routledge.

Corker, M. \& Shakespeare, T. (eds.) (2002) Disability / Postmodernity: Embodying Disability Theory. London: Continuum.

Cox-White, B. \& Boxall, S.F. (2009) Redefining Disability: Maleficent, Unjust and Inconsistent. Journal of Medicine and Philosophy, 33, pp. 558-576.

Crow, L. (1996) Including All of Our Lives: Renewing the Social Model of Disability. In Exploring the Divide: Illness and Disability, eds. C. Barnes \& G. Mercer, pp. 55-74. Leeds: The Disability Press.

Danforth, S. \& Rhodes, W.C. (1997) Deconstructing Disability - a Philosophy for Inclusion. Remedial and Special Education, 18 (6), pp. 357-366.

Harris, J. (2000) Is there a coherent social conception of disability? Journal of Medical Ethics, 26 (2), 95-100.

Oliver, M. (1990) The Politics of Disablement: A Sociological Approach. New York: St. Martin's Press.

Oliver, M. (1996) Understanding Disability: From Theory to Practice. Basingstoke: Macmillan.

Reindal, S.M. (1998) Disability, Personal Autonomy and the Subject - a Dilemma in Special Needs Education? Oslo: Department of Special Needs Education, University of Oslo.

Reindal, S.M. (2000) Disability, Gene Therapy and Eugenics - a Challenge to John Harris. Journal of Medical Ethics, 26 (2), pp. 89-94.

Reindal, S.M. (2008) A Social Relational Model of Disability: A Theoretical Framework for Special Needs Education? European Journal of Special Needs Education, 23 (2), pp. 135-146.

Reindal, S.M. (2009) Disability, Capability, and Special Education: Towards a Capability-Based Theory. European Journal of Special Needs Education, 24 (2), pp. $155-168$.

Richards, J.R. (2002) How Not to End Disability. San Diego Law Review, 39 (3), pp. 693-713.

Terzi, L. (2005) Beyond the Dilemma of Difference: The Capability Approach to Disability and Special Educational Needs. Journal of Philosophy of Education, 39 (3), pp. 443-459.

Thomas, C. (2004) How Is Disability Understood? An Examination of Sociological Approaches. Disability \& Society, 19 (6), pp. 569-583.

Thomas, C. (2007) Sociologies of Disability and Illness Contested Ideas in Disability Studies and Medical Sociology. Houndmills: Palgrave Macmillan.

Tregaskis, C. (2004a) Constructions of Disability. Researching the Interface between Disabled and Non-Disabled People. London: Routledge.

Tregaskis, C. (2004b) Applying the Social Model in Practice: Some Lessons from Countryside Recreation. Disability \& Society, 19 (6), pp. 601-611. 
Vehmas, S. \& Mäkelä, P. (2009) The ontology of disability and impairment. A discussion of the natural and social features. In Arguing about disability philosophical perspectives, eds. K. Kristiansen, T. Shakespeare \& S. Vehmas, pp. 4257. London: Routledge.

WHO (2001) ICF International Classification of Functioning, Disability and Health (short ed.) Geneva: World Health Organization.

WHO (2007) International Classification of Functioning, Disability and Health Children and Youth Version: ICF-CY. Geneva: World Health Organization. 